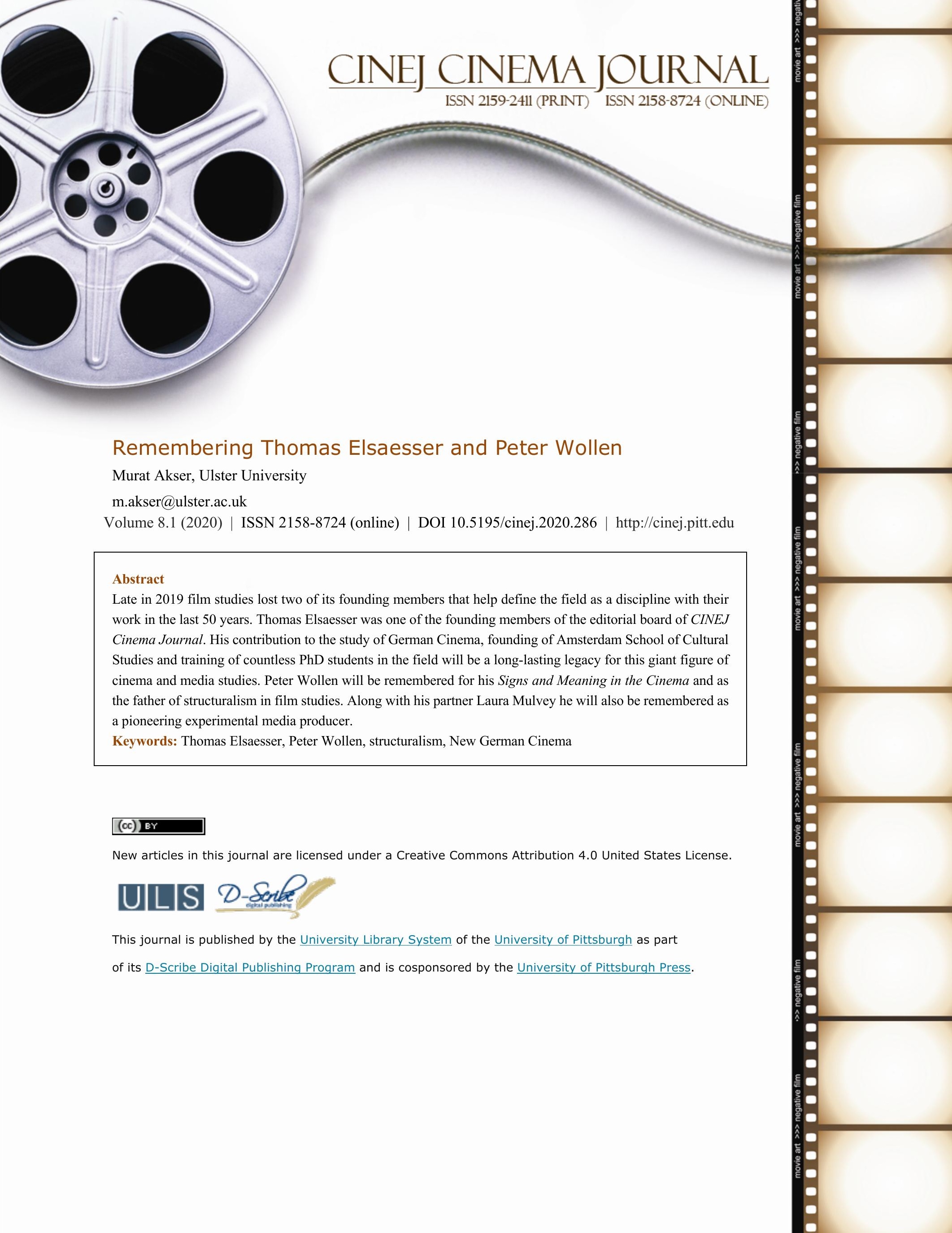




\section{Remembering Thomas Elsaesser and Peter Wollen}

\section{Murat Akser}

There are only a handful of film theorists that are celebrated while alive and revered after their passing (Eyuboglu 2014). Late in 2019 film studies lost two of its founding members that defined it as a discipline in the last 50 years. Thomas Elsaesser (1943-2019) was one of the founding members of the editorial board of CINEJ Cinema Journal. His contributions include a thorough study of German Cinema through several monographs (Elsaesser 1996; Elsaesser 2013), a very influential film theory book (Elsaesser and Hagener 2015), the founding of Amsterdam School of Cultural Studies and the training of countless PhD students in the field. All these efforts and more will be a long-lasting legacy for this giant figure of cinema and media studies. We also lost Peter Wollen (1938-2019) who perhaps will be remembered most for his Signs and Meaning in the Cinema. Wollen's work is not limited to the study of structuralism in film studies though he will most definitely be remembered as the father of this approach. Along with his partner Laura Mulvey Wollen will also be remembered as a pioneering experimental media producer.

After his passing there have been detailed reviews of Thomas Elsaesser's contribution. His work and influence in film studies have been explained in great detail in a special issue of NECSUS (Hagener 2019;Pisters 2019) and in other venues (Buckland 2020). For our part, we are thankful that Thomas was one of the founding editorial board members of CINEJ Cinema Journal. He accepted the odd article review request with great professionalism and dedication. The meeting of a young film scholar with a giant figure like Elsaesser for the first time is both a scholarly and personal interaction at an enormous scale. I have first read his Tales of Sound and Fury article in 1999 as part of York University's MA in Film and Video class. Later I was teaching the same article through course like Film, Media and Society at York. With my first full time film lecturer 
position at KHU, we were able to invite him to deliver one of the keynotes at New Directions in Turkish Film Studies conference. We are also aware of his enormous contribution in supporting and supervision some of our colleagues like Melis Behlil whose work reflects some of the methodological approaches Elsaesser developed over his career (Behlil 2005; Behlil 2016). My work on independent cinema (Akser 2015), film genres (Akser 2010) film festivals, and national cultures/national cinemas (Akser and Durak-Akser 2017; Dinc and Akser 2019) is influenced by his work (Elsaesser 1989; Elsaesser 2018). Some of the daring young scholar work on CINEJ and other alternative film journals are also inspired by Elsaesser's work (see Akser 2012; Varmazi and Erensoy 2017; Dönmez 2018; Erensoy 2018; Ozduzen 2018; Cerrahoğlu Zıraman 2019; Köksal and Baykan 2020).

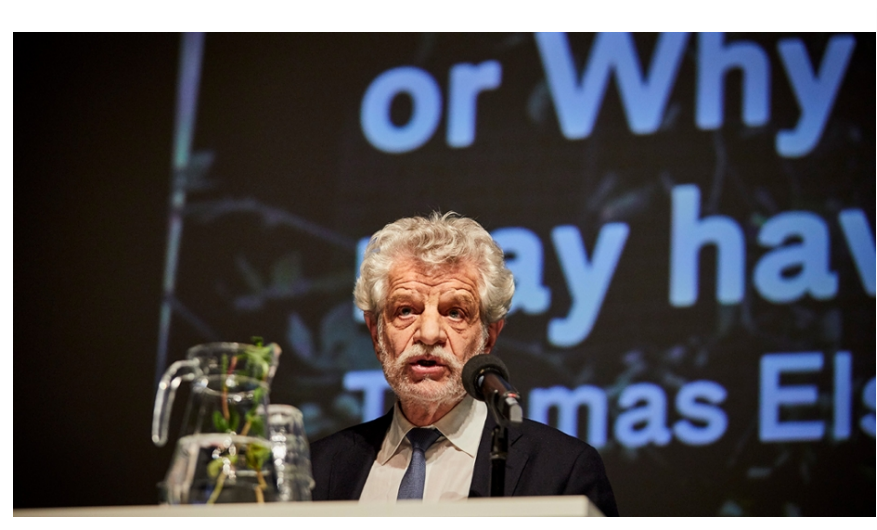

Thomas Elsaesser (1943-2019)

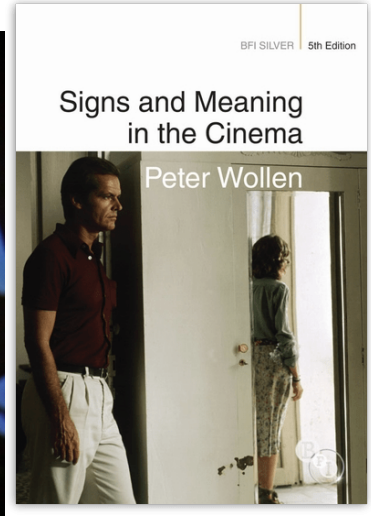

Wollen's classic book

Peter Wollen is celebrated as a film theorist (Wollen 1972; Wollen 1976; Wollen 1999) and also as an art historian and filmmaker. His work with former partner Laura Mulvey like The Riddles of the Sphynx is celebrated among art house cinema. His work encompassed elements of popular culture (Wollen 1993b), British cinema (Wollen 1993a; Wollen 2002) and music video (Wollen 1986). Wollen's impact on filmmaking and film studies are described in detail in the two Sight and Sound essays (Fluke 2019; Miller 2019). 


\section{Hollyn and Buchbinder Remembered}

There have been more film scholars and practitioners who recently passed at the end of 2019. One of them was the former film editor and lecturer at USC, Norman Hollyn (Marble 2019) who will be remembered for his influential books on editing (Hollyn 2009) and directing (Hollyn 2008). The other was Amnon Buchbinder who was a screenwriter, film director, lecturer and book writer (Buchbinder 2005). Buchbinder was a great advocate for his students and encouraged many of them to write feature screenplays some of which he personally directed (like The Fishing Trip see Wood 2006). He had a deep impact in the creation of the undergraduate level screenwriting as one of the streams at York University's Film Department (CFC Staff 2019; YFile 2019).

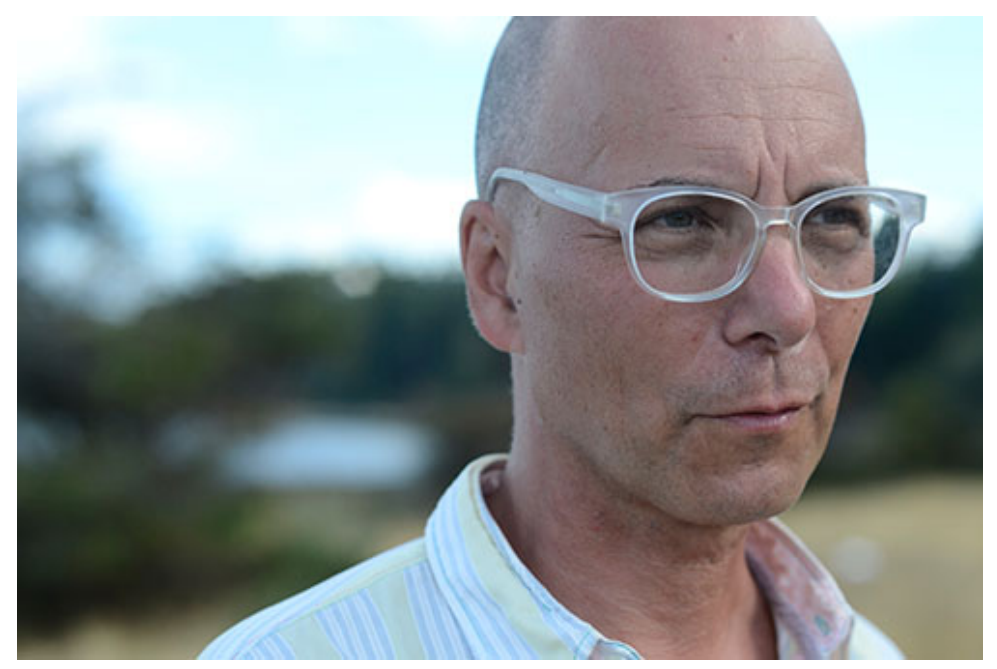

Amnon Buchbinder (1958-2019)

\section{World Developments in Film/Studies}

End of 2019 and the beginning of 2020 presented new challenges to film scholars and practitioners like the emergence of the corona virus outbreak that lead to the cancellation of conferences like IAMCR 2020 in Beijing and ICA 2020 in Australia. Thousands of film theaters 
were closed to prevent the spread of the outbreak, with new James Bond film release pushed six months further. Some film festivals like Fribourg Film Festival were also cancelled. We are to see further impact of the pandemic on both human and artistic levels through 2020 and beyond.

Early 2020 also saw Parasite from South Korea win major awards at the Oscars which is a direct result of the changing of the AMPAS's changing and diverse membership (McCurry and Kim 2020). The film will be one of the most studied films of the next decade (Gabilondo 2020). The guilty verdict of Harvey Weinstein's case (Aratani 2020) shows the impact of the \#MeToo! movement in the USA and around the world (Verhoeven, Coate, \& Zemaityte 2019). The emergence of new guidelines for nudity for actors (Maguire and Dean 2017; Pulver 2020), new scholarships and apprentice programs for women filmmakers across the film industry is a longawaited development.

\section{New Issue of CINEJ}

Volume 8 issue 1 of CINEJ Cinema Journal bring a lineup of high-quality scholarship with unique perspectives. Volkan Yucel's Venom: Desiring Machine (Yucel 2020) focuses on the protagonist in Venom (2018). The article debates on the double character of Eddie-Venom and traces the Deleuzean desire of this folded identity. John Thomas McGuire's "Man in a Hat: Martin Balsam and the Refining of Male Character Acting in American Films, 1957-1976" touches upon the screen acting talent of Martin Balsam, a neglected subject and published for the first time in 
CINEJ (Maguire 2020). Şirin Fulya Erensoy's "Rethinking Pornography within the Context of the New French Extremity: The Case of Baise-Moi' discusses the anxieties the film has unearthed in relation to the alternative depiction of culturally accepted sexual roles and legitimate applications of violent acts, through its subversion of the generic expectations of pornography. Erensoy argues that the film, despite being progressive in form, challenging classical narrative structures and playing with generic tropes, is inherently a pessimistic film, because of its conservative ending that reaffirms the status quo (Erensoy 2020). Leilane Serratine Grubba's 'Cinema, Human Rights and Development: The Cinema as a Pedagogical Practice' looks at another neglected area of film scholarship, the teaching of human rights through cinema. This article seeks to rethink the importance of the cinema as a teaching and learning methodology of Law. To answer the question, "why cinema can be used as an important pedagogical practice to teach human rights? the writer suggests that cinema manages to generate an emotional participation of the spectator, including the student (Grubba 2020).

Ziya Toprak's 'Performing Heteronormativity: The Discourse of the College Hook up Culture and Sexuality' focuses on the college hook up culture and slut discourse. I analyze the documentary feature "Spitting Game: The College Hook Up Culture" that present a provocative sense of the hook up culture. Drawing from the narratives of students presented in the 
documentary, Toprak argues that the college hook up culture is bounded with heteronormativity, where participants of the culture are performing gender positions available to them (Toprak 2020). Paul Animbom Ngong's 'Music and sound in documentary film communication: an exploration of Une Affaire de Nègres and Chef!' examines the function of music and sound as important elements of documentary film communication in two African films. Focusing particularly on testimonies, narrative commentary, filmic silence and music, the study shows how documentary films provide a unique medium to engage an audience in a story of facts and provides a unique vehicle for information transmission. It is once again a rarely touch upon subject which gives a unique exposure to the subject. Omoera and Anyanwu's 'Politics of Succession in Nollywood Films, Saworoide and Ikoka' argues that Nollywood filmmakers have good reasons for shying away from politics, as interesting as it may be; it creates discomfort for governments as well as for the filmmakers. The former on account of their allergy to the truth and the latter on the likelihood of their works being confiscated, banned or even risk to life (Ngong 2020).

Sharrona Pearl's essayistic approach in her 'Deglamming as Estrangement: Ugly in Monster, The Hours, and Cake' introduces a brand-new concept in studying stars and their image in film studies. Pearl explores female actresses undergoing radical or seemingly radical physical transformation in service of a broader kind of career transformation. She problematizes the simple calculation of deglamming, thinking more closely about the ways that celebrity structure raises 
challenges to actors and especially actresses attempting to engage with against-type characters.

Pearl turns specifically to three well-known examples of this trend: Charlize Theron in Monster (2003), Nicole Kidman in The Hours (2002), and Jennifer Aniston in Cake (2014). She argues that the process we see is not about deglamming (or getting ugly) for its own sake. Deglamming in these cases is a process of estrangement: from beauty, from the celebrity machine, from audience expectations. She draws on screen shots, film reviews and interviews to explore the relationship between deglamming and estrangement as a kind of acting and character technique, paying particular attention to the stakes for presenting historical characters in biopics (Pearl 2020).

Finally, Keskin and Baykan in 'Becoming-Animal in the Narrative and the Form of Reha Erdem's Kosmos' argue that Reha Erdem's movie, Kosmos (2009), narrativizes the story of an odd traveler dervish Kosmos, who has supernatural abilities and an expanded capability of communication—one that displays liminal features between human and animal. Through his distinctive editing technique, particularly by juxtaposing human and animal faces, the director further deconstructs the conceptual boundaries between humanity and animality, revealing the inherent connectedness of the two. Hence, this article discloses the consistency between the narrative and the form of Kosmos through a close reading based upon the notion of becominganimal and its conceptual constituents (Keskin and Baykan 2020). 
As usual there are two distinctive book reviews and a list of books received at the end of

the issue. CINEJ is planning to have special sections/special issues through the year. The first two will be on Middle Eastern Cinema and New Horror Cinema in 2020. We will be looking forward to reading these contributions very soon.

\section{BIBLIOGRAPHY}

Akser, M. (2010). Green Pine Resurrected: Film Genre, Parody and Intertextuality in Turkish Cinema. Saarsburcken: Lambert.

Akser, M. (2012). Memory, identity and desire: a psychoanalytic reading of david lynch's mulholland drive. CINEJ Cinema Journal, 2(1), 58-76.

Akser, M. (2015). Turkish independent cinema: Between bourgeois auterism and political radicalism. In Baltruschat, D., \& Erickson, M. P. (Eds.). Independent filmmaking around the globe (pp. 131-148), Toronto: University of Toronto Press.

Akser, M., \& Durak-Akser, D. (2017). Fight for a National Cinema: An Introductory Text and Translation (Halit Refiğ, 1971). Film Studies, 16(1), 56-77.

Aratani, L. (2020). Harvey Weinstein trial shows the divides that exist in \#MeToo movement. The Guardian. 24 February. accessed at: https:/www.theguardian.com/film/2020/feb/24/harveyweinstein-trial-metoo-movement

Behlil, M. (2016). Hollywood is everywhere: global directors in the blockbuster era. Amsterdam: Amsterdam University Press.

Behlil, M. (2005). Ravenous cinephiles: cinephilia, internet, and online film communities. in Marijke de Valck, Malte Hagener eds. Cinephilia: Movies, love and memory, Amsterdam: Amsterdam University Press.

Buchbinder, A. (2005). The way of the screenwriter. Toronto: House of Anansi.

Buckland, W. (2020). In memory of Thomas Elsaesser (1943-2019), New Review of Film and Television Studies, 18(1): 123-125. 
Cerrahoğlu Zıraman, Z. (2019). European co-productions and film style: Nuri Bilge Ceylan. Studies in European Cinema, 16(1), 73-89.

CFC Staff. (2019). In Memoriam: Amnon Buchbinder. December 3. accessed at:

http://cfccreates.com/news/1044-in-memoriam-amnon-buchbinder

Christie, I. (2020) Peter Wollen obituary. Guardian. 8 January. accessed at:

theguardian.com/film/2020/jan/08/peter-wollen-obituary

Dinç, E., \& Akser, M. (2019). Four Women in the Harem (1965) by Halit Refiğg: The Construction of "National Cinema" in Turkey. Journal of Film and Video, 71(4), 51-64.

Dönmez, E. K. (2018). Let's Make it American: American Remakes of the British Films. CINEJ Cinema Journal, 7(1), 238-261.

Elsaesser, T. (2018). European Cinema and Continental Philosophy: Film as Thought Experiment. London: Bloomsbury Publishing USA.

Elsaesser, T., \& Hagener, M. (2015). Film theory: An introduction through the senses. London: Routledge.

Elsaesser, T. (2013). Weimar cinema and after: Germany's historical imaginary. London: Routledge.

Elsaesser, T. (2009). The mind-game film. in 'W. Buckland ed. Puzzle films: Complex storytelling in contemporary cinema, London: Wiley-Blackwell. 13-41.

Elsaesser, T. (2005a). European cinema: Face to face with Hollywood. Amsterdam: Amsterdam University Press.

Elsaesser, T. (2005b). Cinephilia or the Uses of Disenchantment. in Marijke de Valck, Malte Hagener eds. Cinephilia: Movies, love and memory, Amsterdam: Amsterdam University Press. 27-43.

Elsaesser, T. (2005c). Film festival networks: The new topographies of cinema in Europe. in T.Elsaesser ed. European Cinema: Face to Face with Hollywood, Amsterdam: Amsterdam University Press. 82-106.

Elsaesser, T. (2004). The new film history as media archaeology. Cinémas: revue d'études cinématographiques/Cinémas: Journal of Film Studies, 14(2-3), 75-117. 
Elsaesser, T., \& Buckland, W. (2002). Studying contemporary american film: A guide to movie analysis, London: Arnold.

Elsaesser, T. (2001a). The Blockbuster: Everything Connects, but not Anything goes. in Jon Lewis ed. The End of Cinema-as we know it: american film in the nineties, London: Pluto Press, 11-22.

Elsaesser, T. (2001b). Postmodernism as mourning work. Screen, 42(2), 193-201.

Elsaesser, T. (1996). Fassbinder's Germany: history, identity, subject. Amsterdam: Amsterdam University Press.

Elsaesser, T. (1989) New German cinema: a history. London: British Film Institute.

Elsaesser, T. (1986). The" new" film history. Sight and Sound, 246.

Elsaesser, T. (1972). Tales of sound and fury: Observations on the family melodrama. Monogram, 4:2-15.

Erensoy, Ş.F. (2020) Rethinking Pornography within the Context of the New French Extremity: The Case of Baise-Moi'. CINEJ Cinema Journal. 8(1), 60-86.

Erensoy, Ş.F. (2018) Approaches to othered identities and spaces in french cinema. In: Harvey J. (eds) Nationalism in Contemporary Western European Cinema. Palgrave Macmillan

Eyüboğlu, S. (2014). "The Radical Novelty of Robin Wood's Political Film" in M. Akser and D. Bayrakdar eds. New Cinema, New Media: Reinventing Turkish Cinema, Newcastle: Cambridge Scholars Press.

Fluke, O. (2019) Path of most resistance: the films of Laura Mulvey and (the late) Peter Wollen in tribute. Sight and Sound. December 20. accessed at: https://www.bfi.org.uk/news-opinion/sightsound-magazine/features/laura-mulvey-peter-wollen-film-overview

Gabilondo, J. (2020). Bong Joon Ho's Parasite and post-2008 Revolts: From the Discourses of the Master to the Destituent Power of the Real. International Journal of Žižek Studies, 14(1), 1-21.

Grubba, L.S. Cinema, human rights and development: the cinema as a pedagogical practice. CINEJ Cinema Journal. 8(1), 87-123.

Hagener, M. (2019) Stories we tell: Remembering Thomas Elsaesser. retrieved at: https://necsusejms.org/stories-we-tell-remembering-thomas-elsaesser/

Hollyn, N. (2009). The film editing room handbook: how to tame the chaos of the editing room. Peachpit Press.

Hollyn, N. (2008). The Lean forward moment: create compelling stories for film, $t v$, and the Web. New riders. 
Karbalaeetaher, H. Cinema and society in the light of emile zola's naturalism. CINEJ Cinema Journal. 8(1), 141-155.

Keskin, S. and Baykan, B. (2020). Becoming-Animal in the Narrative and the Form of Reha Erdem’s Kosmos. CINEJ Cinema Journal. 8(1), 249-285.

Köksal, E. and Baykan, B. (2020) The materiality of reality: the floating consciousness in altered carbon. in Aldona Kobus, Lukasz Muniowski eds. Sex, death and resurrection in altered carbon: essays on the netflix series. McFarland.

Kooijman, J., Pisters, P., \& Strauven, W. (Eds.). (2008). Mind the Screen: media concepts according to Thomas Elsaesser. Amsterdam: Amsterdam University Press.

McGuire, J.T. Man in a hat: martin balsam and the refining of male character acting in american films, 1957-1976. CINEJ Cinema Journal. 8(1), 30-59.

Maguire, T. and Dean, T. (2017) How training for stage and screen can combat bullying and abuse. RTE Brainstrom. 7 November. accessed at: https://www.rte.ie/brainstorm/2017/1107/918042how-training-for-stage-and-screen-can-combat-bullying-and-abuse/

Marble, S. (2019) Norman Hollyn, USC professor, film editor who worked on 'Sophie's Choice,' dies at 66. Los Angeles Times. 20 March. accessed at: https://www.latimes.com/local/obituaries/lame-norman-hollyn-dead-20190320-story.html

McCurry, J. and Kim, N. Parasite: how Oscar triumph has exposed South Korea's social divide. The Observer 16 February. accessed at: https:/www.theguardian.com/film/2020/feb/16/parasitefilm-oscars-bong-joon-ho-seoul-rich-poor-south-korea

Miller, H.K. (2019) Peter Wollen obituary: the maven of British film theory. Sight and Sound. December 19. accessed at: https:/www.bfi.org.uk/news-opinion/sight-soundmagazine/comment/obituaries/peter-wollen-film-theory-modernism-signs-meaning-riddlessphinx-passenger

Ngong, P.A. (2020) Music and sound in documentary film communication: an exploration of Une Affaire de Nègres and Chef! CINEJ Cinema Journal 8(1), 156-184.

Omoera, O.S. and Anyanwu, C. Politics of Succession in Nollywood Films, Saworoide and Ikoka. CINEJ Cinema Journal. 8(1), 185-217.

Ozduzen, O. (2018). Cinema-going during the Gezi protests: claiming the right to the Emek movie theatre and Gezi Park. Social \& Cultural Geography, 19(8), 1028-1052. 
Pearl, S. (2020). Deglamming as Estrangement: Ugly in Monster, The Hours, and Cake. CINEJ Cinema Journal. 8(1), 218-248.

Pisters, P. (2019) In Memoriam, Thomas Elsaesser. retrieved at: https://necsus-ejms.org/inmemoriam-thomas-elsaesser/

Pulver, A. (2020). Actors' union creates 'landmark' rules for filming sex scenes. The Guardian. 30 January. accessed at; https://www.theguardian.com/film/2020/jan/30/actors-union-landmarkrules-filming-sex-scenes-screen-actors-guild-intimacy-coordinators

Toprak, Z. (2020) Performing Heteronormativity: The Discourse of the College Hook up Culture and Sexuality. CINEJ Cinema Journal 8(1), 124-140.

Verhoeven, D., Coate, B., \& Zemaityte, V. (2019). Re-Distributing Gender in the Global Film Industry: Beyond\# MeToo and\# MeThree. Media Industries Journal, 6(1).

Wollen, P. (2002). Paris Hollywood: Writings on Film. London: Verso.

Wollen, P. (2001). Bitter victory: The art and politics of the Situationist International.

Wollen, P. (1999). La règle du jeu and modernity. Film Studies, 1(1), 5-13.

Wollen, P. (1993a). The last new wave: modernism in the British films of the Thatcher era. Fires were started: British cinema and Thatcherism, 35-51.

Wollen, P. (1993b). Raiding the icebox: reflections on twentieth-century culture. London: Verso.

Wollen, P. (1986). Ways of thinking about music video (and post-modernism). Critical Quarterly, 28(1), 167-170.

Wollen, P. (1976). 'Ontology' and 'Materialism' in Film. Screen, 17(1), 7-25.

Wollen, P. (1972). Signs and Meaning in the Cinema. Bloomington: Indiana University Press.

Wood, R. (2006). Two films by Amnon Buchbinder: some questions about the future of Canadian cinema. CineAction, (69), 69-73.

YFile (2019). Passings: Amnon Buchbinder, filmmaker, director and screenwriter. December 4. accessed at: https://yfile.news.yorku.ca/2019/12/04/passings-amnon-buchbinder-filmmakerdirector-and-screenwriter/

Yucel, V. (2020). Venom: A Desiring Machine. CINEJ Cinema Journal. 8(1), 14-29. 